\title{
Crypt cell production rates at various sites around the colon in Wistar rats and humans
}

\author{
C Hall, D Youngs, M R B Keighley
}

\begin{abstract}
The crypt cell production rate (CCPR) is considered the most robust estimate of cell turnover. The CCPR was determined at various sites around the colon in the Wistar rat (using an in vivo technique) and in six healthy humans (using in vitro organ culture). In both the rat and human colon, the CCPR increased proximally from the rectum to the caecum. The caecum had a significantly higher cell turnover than any other site in the colon $(p<0.05$ in the rat, $p<0.01$ in humans, Student's $t$ test). These findings are of interest when considering cellular proliferation studies in both inflammatory bowel disease and colorectal cancer, and draw attention to the importance of choosing a constant reference site for comparative studies. This is the first time the CCPR had been measured along the length of the human colon.
\end{abstract}

(Gut 1992; 33: 1528-1531)

The crypt cell production rate (CCPR) estimates cell turnover by determining growth fraction, cell cycle time, and crypt population - this stathmokinetic technique is the only method of achieving this.' It can be performed in vivo by administration of a metaphase arresting agent to the animal under study and taking subsequent biopsy specimens or in vitro by addition of a metaphase arresting agent to an organ culture system containing multiple biopsy specimens that can then be removed sequentially. Because of ethical considerations, the in vitro technique is the only one suitable in man.

Animal studies comparing the small with the large intestine have shown site variation in cell turnover. ${ }^{2}$ The rat colon, in particular, has been studied using autoradiography ${ }^{3}$ and the stathmokinetic technique, ${ }^{4}$ and the right side of the colon has been shown to have a more rapid cell turnover rate than the left.

In this study, we have confirmed that the rat colon displays a higher CCPR in the caecum and we have demonstrated the same findings in man using the in vitro technique.

\section{Methods}

Department of Surgery Birmingham General Hospital, Birmingham C Hall D Youngs

M R B Keighley

Correspondence to:
Mrs C Hall, Department of Mrs Cery, Queen Elizabeth Surgery, Queen Elizabeth Medical Centre, Edgbas
Birmingham B15 2TH Birmingham B15 2TH 11 May 1992

\section{RAT STUDY - IN VIVO ESTIMATION OF CCPR}

Fifteen female Wistar rats were housed five to a cage and allowed standard laboratory chow and water ad libitum. At 25 weeks, vincristine was administered intraperitoneally at a dose of $1 \mathrm{mg} /$ $\mathrm{kg}$, a dose predetermined to produce adequate metaphase arrest. One animal was sacrificed after vincristine injection at each of the following five time points: $60,90,120,150$, and 180 minutes and one CCPR estimation was obtained. The experiment was repeated three times with animals numbered $1-5,6-10$, and $11-15$ respectively to obtain three individual CCPRs.

The colon of each animal was removed, opened down the antimesenteric border, cleaned, and pinned on a cork board. A $1 \mathrm{~cm}^{2}$ strip of colon was taken at distances $25 \%, 50 \%$, $75 \%$, and $100 \%$ from the anal verge and placed in Carnoy's solution for two hours. The specimens were then transferred to $70 \%$ ethanol for storage.

HUMAN STUDY - IN VITRO ESTIMATION OF CCPR Six female patients (age range $31-46$ years) who underwent total colectomy and ileorectal anastomosis for chronic constipation not relieved by conventional means were studied. They were all fit and had no other history of bowel disease.

After standard bowel preparation with Picolax (sodium picosulphate (10 $\mathrm{mg}$ ) and magnesium oxide $(3.5 \mathrm{~g})$ ) the patient was anaesthetised and placed in Lloyd Davies stirrups. A rectal biopsy specimen was taken via a rigid sigmoidoscope posteriorly, $10 \mathrm{~cm}$ from the anal verge. A total colectomy and ileorectal anastomosis was then performed. The whole colon was mobilised from sigmoid to caecum before dividing the ileocolic, right, middle, left colic, and inferior mesenteric arteries to minimise colonic ischaemia. The colon was immediately opened along the antimesenteric border and washed clean. A $1 \mathrm{~cm}^{2}$ mucosal biopsy specimen was taken from the sigmoid, descending, transverse, and ascending colon, and the caecum.

The method used was that described by Allan and Jewell. ${ }^{5}$ All solutions and instruments used were sterile,and asepsis was observed to avoid bacterial contamination of the culture. The biopsy specimens were placed in $0.9 \%$ saline in a Petri dish at room temperature and diced into 2 $\mathrm{mm}$ cubes (explants). Each explant was transferred to a wire grid placed in the centre of an organ culture dish containing $1 \mathrm{ml}$ of organ culture medium (RPMI 1640 with $25 \mathrm{mM}$ Hepes buffer and $2 \mathrm{mM}$ glutamine, Roswell Park Memorial Institute). This was supplement with inactivated fetal calf serum $10 \% \mathrm{vol} / \mathrm{vol}$ Penicillin $(0.6 \mathrm{mg} / \mathrm{ml})$ and gentamicin $(0.04$ $\mathrm{mg} / \mathrm{ml}$ ) were added to inhibit bacterial growth.

The explants were orientated luminal surface uppermost and maintained at the gas/liquid interphase such that the luminal surface was just coated with the meniscus of the organ culture medium. The culture dish was then placed in a gas tight jar equilibrated with $95 \% \mathrm{O}_{2} / 5 \% \mathrm{CO}_{2}$ and maintained in a water bath at $37^{\circ} \mathrm{C}$.

After 16 hours in culture, the medium was aspirated from the central well and replaced by identical medium containing the predetermined 
dose of vincristine to induce optimal metaphase arrest $(0.5 \mu \mathrm{g} / \mathrm{ml})$. Explants were removed at 60 , 120, and 180 minutes and fixed in Carnoy's solution for two hours after which they were transferred to $70 \%$ ethanol for storage.

\section{COUNTING METAPHASE ARREST FIGURES}

In both the rat and human studies the samples were coded and the metaphase arrests were counted by an independent observer (D Youngs). The explants were rehydrated in $50 \%$ and then $25 \%$ ethanol and stained by the Feulgen reaction to enhance DNA staining. Individual crypts were microdissected using a binocular microscope and metaphase arrest figures counted in each of 10 complete crypts. Linear regression analysis of the slope, generated by plotting the number of metaphases against the time interval, gave the CCPR in cells/crypt/hour.

\section{Results}

It has been our experience that severe ischaemia or non-viability of the tissue in culture, for whatever reason, results in a gelatinous lump of tissue that will not microdissect satisfactorily to allow 10 individual crypts to be identified and counted. No such tissue was found in any of these reported results. The individual CCPR and the mean CCPR (SEM) for each site are given in Tables I (rat data) and II (human data). The CCPR is measured in cells/crypt/hour. Statistical analysis was performed by Student's $t$ test.

In the Wistar rat, the CCPR of the caecum, which was represented by the $100 \%$ biopsy site, was signficantly higher than that of the $75 \%$ site $(p<0.05)$ and the $25 \%$ site $(p<0.05)$, and although higher than the midpoint of the colon,

TABLE I Effect of site on crypt cell production rate $(C C P R)$ in the rat colon

\begin{tabular}{|c|c|c|c|}
\hline Site & $\begin{array}{l}\text { Animal } \\
\text { no }\end{array}$ & $\begin{array}{l}\text { Individual } \\
C C P R\end{array}$ & $\begin{array}{l}\text { Mean } \\
(S E M) \\
C C P R\end{array}$ \\
\hline $\begin{array}{l}100 \% \\
\text { (caecum) }\end{array}$ & $\begin{array}{c}1-5 \\
6-10 \\
11-15\end{array}$ & $\left.\begin{array}{l}5 \cdot 76 \\
7 \cdot 94 \\
9 \cdot 29\end{array}\right\}$ & $7 \cdot 67(1 \cdot 03)$ \\
\hline $75 \%$ & $\begin{array}{c}1-5 \\
6-10 \\
11-15\end{array}$ & $\left.\begin{array}{r}2.92 \\
11 \cdot 00 \\
9 \cdot 70\end{array}\right\}$ & $3.86(0.65)$ \\
\hline $50 \%$ & $\begin{array}{c}1-5 \\
6-10 \\
11-15\end{array}$ & $\left.\begin{array}{l}4 \cdot 27 \\
5 \cdot 06 \\
2 \cdot 67\end{array}\right\}$ & $4 \cdot 15(0 \cdot 57)$ \\
\hline $\begin{array}{l}25 \% \\
\text { (rectum) }\end{array}$ & $\begin{array}{r}1-5 \\
6-10 \\
11-15\end{array}$ & $\left.\begin{array}{l}3 \cdot 22 \\
3 \cdot 58 \\
3 \cdot 36\end{array}\right\}$ & $2.99(0.43)$ \\
\hline
\end{tabular}

CCPR was measured in cells/crypt/hour.

TABLE II Effect of site on crypt cell production rate $(C C P R)$ in the human colon

\begin{tabular}{|c|c|c|c|c|c|c|c|}
\hline \multirow[b]{2}{*}{ Site } & \multicolumn{7}{|l|}{$C C P R$} \\
\hline & Patient 1 & Patient 2 & Patient 3 & Patient 4 & Patient 5 & Patient 6 & $\operatorname{Mean}(S E M)$ \\
\hline $\begin{array}{l}\text { Caecum } \\
\text { Ascending } \\
\text { colon }\end{array}$ & $\begin{array}{c}14 \cdot 05 \\
5 \cdot 7\end{array}$ & $\begin{array}{l}7 \cdot 6 \\
7 \cdot 3\end{array}$ & $\begin{array}{l}8 \cdot 8 \\
2 \cdot 8\end{array}$ & $\begin{array}{l}4 \cdot 65 \\
0 \cdot 49\end{array}$ & $\begin{array}{l}12 \cdot 5 \\
0 \cdot 6\end{array}$ & $\begin{array}{l}4 \cdot 85 \\
2 \cdot 3\end{array}$ & $\begin{array}{l}8 \cdot 74(1.59) \\
3 \cdot 19(1.13)\end{array}$ \\
\hline $\begin{array}{l}\text { Transverse } \\
\text { colon }\end{array}$ & $2 \cdot 2$ & $8 \cdot 7$ & $2 \cdot 15$ & $0 \cdot 8$ & 0.5 & $0 \cdot 75$ & $2 \cdot 51(1 \cdot 27)$ \\
\hline $\begin{array}{l}\text { Descending } \\
\text { colon }\end{array}$ & $4 \cdot 6$ & $8 \cdot 2$ & 1.6 & $1 \cdot 1$ & 1.5 & $0 \cdot 7$ & $2 \cdot 95(1 \cdot 19)$ \\
\hline $\begin{array}{l}\text { Sigmoid } \\
\text { colon }\end{array}$ & $9 \cdot 25$ & $2 \cdot 5$ & $5 \cdot 6$ & $2 \cdot 75$ & 0.9 & $0 \cdot 3$ & $3 \cdot 54(1 \cdot 36)$ \\
\hline Rectum & $5 \cdot 3$ & $9 \cdot 4$ & $5 \cdot 5$ & $0 \cdot 85$ & 0.5 & $2 \cdot 05$ & $3.93(1.40)$ \\
\hline
\end{tabular}

CCPR was measured in cells/crypt/hour. the difference in CCPRs did not quite reach significance.

In the human colon, the CCPR of the caecum was significantly higher than that of any other site in the colon or rectum $(p<0 \cdot 01)$.

Hence, in both the rat and in humans, it has been demonstrated that the CCPR is significantly higher in the right colon than in the rest of the large bowel.

\section{Discussion}

The stathmokinetic method of estimating cellular proliferation by estimating the CCPR provides a firm kinetic parameter that is sensitive to changes in cell cycle time, growth fraction, and crypt population size. The regression slopes are readily comparable with those of other groups and measurements are completed in three hours so that rapid adaptive responses are not missed. Moreover, there are no hidden errurs from the use of sectioned material, as whole microdissected crypts are counted, and the method is economical in terms of animals, time, expenditure, and labour.

There are, of course, many other methods of estimating cellular proliferation, although each has inherent faults. Straightforward morphometric methods of measuring villus height, intestinal length, surface area, and dry weights are subject to great interobserver error and are very crude, rarely used methods.

The main static methods are those of measuring the mitotic or labelling indices. The mitotic index is simply the number of cells in the $M$ phase of the cell cycle at any given time. It cannot distinguish between changes in the proportion of cells in mitosis and changes in the duration of mitosis.

The labelling index is more accurate than the mitotic index and relies on pulse labelling of nuclear DNA using tritiated thymidine. However, tritiated thymidine is not a precursor in the de novo synthesis of DNA and is incorporated by a salvage pathway not used by most renewing cell systems. The incorporation of the isotype is affected by the activity of the incorporating enzymes, the size of the endogenous thymidine pool, and the rate of transport of the isotope through the cell membrane. Dying cells releasing nucleotides and uptake by bacteria may also influence the results obtained with this method.

Measurement by fraction labelled mitoses is better than the labelling index but it takes at least 15 hours, will miss rapid changes in proliferation, and is expensive in terms of isotope, animal, and labour. ${ }^{6}$

Many groups are now using a pyrimidine analogue of thymidine, bromodeoxyuridine. The efficacy of pulse labelling in vivo is influenced by blood supply and the time between labelling the cells and sampling them. Thus, cells which are inaccessible to the analogue for various reasons may not be labelled. Analysis of the incorporated bromodeoxyuridine with monoclonal antibodies requires DNA to be denatured, which leads to cell loss and possible damage to antigenic sites.

More recently, cellular proliferation has been studied by utilising a mouse monoclonal antibody Ki67 that identifies a nuclear antigen 
associated with the cell cycle. There is good correlation between Ki67 immunoreactivity and other indices of cellular proliferation, but again it is a static not a dynamic measurement and provides information as to the state, not the rate of proliferation. ${ }^{8}$

This study has confirmed previous work with the rat colon showing that the CCPR increases proximally from the rectum to the caecum. ${ }^{34}$ However, this is the first time that the human colon has been studied in this way and it is interesting that the same trend has been shown despite several assumptions made in the study design which are detailed below. Kinetic studies in man are limited by ethical restraints. It is, of course, impossible to use in vivo methods in humans but the in vitro method has been shown to correlate well with the in vivo technique in the animal model ${ }^{10}$ and hence was utilised for this study.

Although there may be some pathological process that results in chronic constipation, it is unlikely to be mucosal in origin, and so tissue from patients undergoing total colectomy for constipation seemed to be a reasonable option for investigation of cell turnover throughout the colon. Light microscopy was performed to ensure that the mucosa was completely normal. Nonetheless, these patients had been subjected to a 48 hour period of liquid diet and bowel preparation which must have had some effect on the absolute CCPR in the colon. ${ }^{12}$ Similarly, operative ischaemia must have altered the CCPR, ${ }^{12}$ although the degree of ischaemia was not so pronounced as to prevent successful organ culture. However, as both these factors affected the whole length of the large bowel equally, it was felt that the trends shown are valid observations.

It may be possible to study colons discovered to be normal at colonoscopy performed to investigate large bowel symptoms. This would obviate the problem of ischaemia, although of course the effect of bowel preparation would still remain. However, our experience of this method was that the biopsy specimens obtained by the colonoscopic biopsy forceps were often too small to allow a minimum of 10 whole crypts to be microdissected. The length of time it took to gather three specimens from each of the six sites resulted in a delay either in placing the specimens in the culture medium or in equilibrating them in $95 \% \mathrm{O}_{2} / \mathrm{CO}_{2}$, leading to suboptimal culture. It was difficult to ensure that the tissue was always taken from the area stated by the colonoscopist as the colonoscope 'concertinas' the bowel onto itself making it sometimes impossible to tell exactly where in the sigmoid or transverse colon the biopsy had been taken. By opening up the operative specimen of the colon, specimens could be taken precisely from each anatomical region.

Finally, there is the small but definitive risk of colonoscopic perforation ${ }^{1314}$ and we felt ethically unjustified in subjecting a normal subject to 18 colonoscopic biopsies for research purposes only.

The finding that the caecum seems to have a higher turnover rate than the rest of the colon is important in two ways. Firstly any comparative study of diseased and normal areas of mucosa within the same person or between different subjects must take into account the normal variation in background CCPR and ensure standardised reference points for biopsy as far as possible. Failure to allow for this fact will invalidate results.

Secondly, there are important implications when applying cellular kinetics to the study of carcinogenesis. Using the various less robust methods of estimating cell turnover, it has been shown that there seems to be an increase in cell turnover in polyposis coli,${ }^{15}$ ulcerative colitis ${ }^{16}$ in mucosa adjacent to an established carcinoma, ${ }^{17}$ and in fact in the entire colonic mucosa of patients with a carcinoma. ${ }^{18}$ We have shown that the natural CCPR in the caecum is higher than that in the rest of the colon, yet most of human colorectal cancers and experimental animal cancers are left sided. ${ }^{19}$ Cooke et al took their study one stage further. They examined the CCPR throughout the rat colon and showed that it was the percentage increase in the CCPR that was important in carcinogenesis, not the absolute value. ${ }^{4}$ Moreover, despite its higher cell turnover rate, it seems that the caecum has a natural resistance to carcinogenesis, for distal transposition in an animal model does not increase either its CCPR or tumour yield. ${ }^{20}$

The finding that the human colon behaves like its animal counterpart is important for several reasons. It further supports the use of the Wistar rat as a model for human colonic studies. It emphasises the fact that the absolute value of the CCPR is of no importance when studying carcinogenesis whereas the percentage change in CCPR is probably far more interesting. However, what is of paramount importance is the fact that we have confirmed that there is site to site variation within the human colon. Careful choice of reference site in comparative studies is therefore essential to ensure valid results and conclusions.

We thank Mrs E Grant for her help with the animal work and Mr R C Hinman for typing this manuscript.

1 Al-Mukhtar MYT, Polak JM, Bloom SR, Wright NA. The search for appropriate measurements of proliferative and morphological status in studies on intestinal adaptation. In: Robinson JWL, Dowling H, Reicken EO, eds. Mechanisms of intestinal adaptation. Lancaster: MTP Press 1982: 3-28. Eastwood GL. Gastrointestinal epithelial renewal. Gastroenterology 1977; 72: 962-5.

enterology 1977; 72: 962-5.
Sunter JP, Wright NA, Appleton DR. Cell population kinetics in epithelium of the colon of the male rat. Virchows Arch [B]. 1978; 26: 275-7.

4 Cooke T, Kirkham N, Stainthorp DH, Inman C, Goeting N, Taylor I. Detection of early neoplastic changes in experimentally induced colorectal cancer using scanning electron

5 Allan A, Jewell DP. An in vitro model for assessment of luminal factors on rectal mucosa. Gut 1983; 24: 812-7.

6 Goodlad RA, Wright NA. Quantitative studies on epithelial replacement in the gut. In: Trichen DA, ed. Techniques in digestive physiology. Elsevier Scientific Publishers Ireland, 1982: 1-23.

7 Williamson KE, Hamilton PW, Grimes J, Gilliland R. Advances in cell kinetics. BMF 1991; 303: 855-6.

$8 \mathrm{Yu}$ CCW, Woods AL. Immunohistochemical methods of Yu CCW, Woods AL. Immunohistochemical methods of
assessing cellular proliferation. Surgery 1991; 92: 2216b-c. 9 Finney KJ, Ince P, Appleton DR, Sunter JP, Watson AJ. A comparison of crypt cell proliferation in rat colonic mucosa in vivo and in vitro. $\mathcal{F}$ Anat $1986 ; 149: 177-8$.

10 Hall C. Cell turnover in mucosa at risk of colorectal cancer. Liverpool, 1990. (Thesis.)

11 Goodlad RA, Wright NA. Effect of starvation and refeeding on intestinal cell proliferation in the mouse. Virchows Arch [B] 1984; 45: 63-73.

12 Pritchett CJ, Senior PV, Sunter JP, Watson AJ, Appleton DR, Wilson RG. Human colorectal tumours in short term organ culture. A stathmokinetic study. Cell Tissue Kinet 1982; 15: $555-4$.

13 Frümorgen P, Demling L. Complications of diagnostic and therapeutic colonoscopy in the Federal Republic of Germany. Results of an enquiry. Endoscopy 1979; 2: 146-50. 
14 Macrae FA, Tan KG, Williams CB. Towards safer colonoscopy: a report on the complications of 5000 diagnostic or therapeutic colonoscopies. Gut 1983; 24: 376-83.

15 Bleiburg H, Mainguet P, Galand P. Cell renewal in familial polyposis: Comparison between polyps and adjacent healthy mucosa. Gastroenterology 1972; 63: 240-5.

mucosa. Gastroenterology 1972; 63: $240-5$.
16 Eastwood GL, Trier JS. Epithelial cell renewal in cultured rectal biopsies in ulcerative colitis. Gastroenterology 1973;64: rectal biopsies in ulcerative colitis. Gastroenterology 1973; 64:

17 Deschner EE, Salmon RJ. Cell kinetics of gastrointestinal cancer and its precursor states. In: Decosse JJ, Sherlock P, eds. Gastrointestinal cancer 1. Martinus Hijhoff, 1981: $1-27$.

18 Terpestra OT, Van Blankenstein M, Dees J, Eilers GAM. Abnormal pattern of cell proliferation in the entire colonic mucosa of patients with colon adenoma or cancer. Gastromucosa of patients with colon adenoma or cancer. Gastro19 De Jong VW $1987 ; 92: 704-8$

Jong Wuir CS, et al. The distribution of cancer within the large bowel. Int $\mathcal{F}$ Cancer 1972; 10: 463-77. 20 Rainey JB, Maeda M, Williamson RCN. Distal transposition of rat caecum does not render it susceptible to carcinogenesis. Gut 1985; 26: 718-23. 